\title{
Transposition of the great arteries with ventricular septal defect and pulmonary stenosis
}

\author{
FRANK A. W. VAN GILS, ANDRE J. MOULAERT, ARENTJE OPPENHEIMER- \\ DEKKER, AND ARNOLD C. G. WENINK \\ From the Division of Congenital Heart Malformations, Department of Anatomy and Embryology, State \\ University, Leiden, and the Department of Pediatric Cardiology, University Childrens Hospital, Wilhelmina \\ Kinderziekenhuis, Utrecht, The Netherlands
}

SUMMARY A postmortem investigation was carried out of 19 heart specimens with transposition of the great arteries, ventricular septal defect, and congenital subvalvular pulmonary stenosis. Certain types of obstruction appeared to be closely related to other features of the hearts.

In cases with malalignment of the infundibular septum, the obstruction was caused by this septum and the anterolateral muscle bundle of the left ventricle. If the infundibular septum was deviated considerably to the left, the pulmonary stenosis was usually severe because the infundibular septum and anterolateral muscle bundle were joined. This junction resulted in a relatively posterior position of the pulmonary orifice in the left ventricle. A less extreme deviation of the infundibular septum resulted in an obstruction by this septum and by the anterolateral muscle bundle, situated at the right and the left sides of the pulmonary orifice respectively.

In some cases of paratricuspid ventricular septal defect an anomalously attached and cleft anterior leaflet of the mitral valve was found. This, together with a leftward deviation of the anterior left ventricular part of the ventricular septum, caused the obstruction.

Subvalvular pulmonary stenosis in transposition of the great arteries with ventricular septal defect comprises a variety of obstructing factors, summed up within one term. The obstruction may vary from a single one to a combination of several complex abnormal structures and orientations (Elliott et al., 1963; Shaher et al., 1967a, 1967b; Daicoff et al., 1969; Rastelli et al., 1969; Fisher et al., 1970; Imamura et al., 1971; Quero-Jiménez et al., 1973; Shaher, 1973; Quero-Jiménez and Pérez Martínez, 1974; Lancelin et al., 1975; QueroJiménez et al., 1975; Shrivastava et al., 1976; Bühlmeyer et al., 1977; Quero-Jiménez et al., 1977; Van Praagh, 1977).

If we exclude cases with other malformations, nonvalvular pulmonary stenosis in transposition of the great arteries with ventricular septal defect in the published reports is described in about 7 to 25 per cent of cases of transposition coming to necropsy (Lev et al., 1961; Elliott et al., 1963; Shaher et al., 1967b; Paul et al., 1968; Imamura et al., 1971; Quero-Jiménez et al., 1973; Shaher, 1973; Van Praagh, 1977).

Received for publication 1 August 1977
In our collection of 150 heart-lung specimens with d-transposition of the great arteries, there were 19 specimens with the combination transposition of the great arteries, ventricular septal defect, and clinical subvalvular pulmonary stenosis. In this paper a detailed description is given of the various structures, causing the subvalvular stenosis.

\section{Definitions}

Transposition of the great arteries is said to occur when the aorta arises from the morphologically right ventricle and the pulmonary trunk arises from the morphologically left ventricle. The infundibular septum is the structure interposing between two semilunar valves (Lev, 1972; Anderson et al., 1977), and in normal hearts it is incorporated on top of the ventricular septum; in the case of a malorientation of the infundibular septum a malalignment ventricular septal defect may result (Fig. 1a, 2a). The anterolateral muscle bundle of the left ventricle separates the anterior leaflet of the mitral valve from the anterior border of the left ventricle. It borders on the left sumilunar cusp and extends into the anterolateral wall of the left ventricle (Fig. 1b, 2b) 

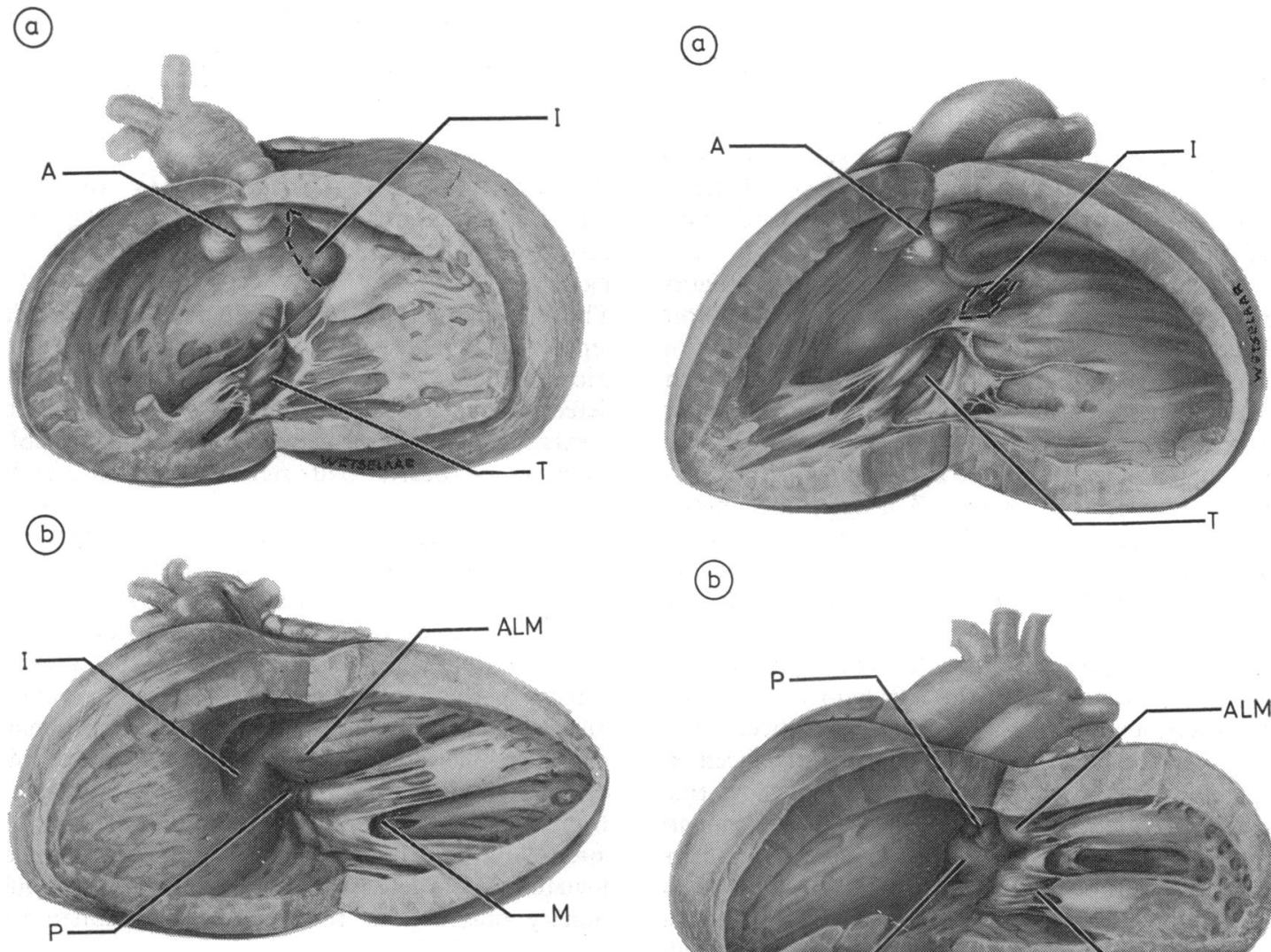

Fig. 1(a) Interior of the right ventricle of a heart with transposition of the great arteries and malalignment ventricular septal defect with extreme leftward deviation of the infundibular septum $(I)$. The ventricular septal defect is partly bounded by aortic valve cusp, and is indicated by a dotted line. A, aortic orifice; $T$, tricuspid orifice. (b) Interior of the left ventricle; same heart as Fig. 1a. The anterolateral muscle bundle of the left ventricle $(A L M)$ is present, it joins the infundibular septum $(I)$. The pulmonary orifice $(P)$ is displaced posteriorly. $M$, mitral orifice.

(Moulaert, 1974; Moulaert and OppenheimerDekker, 1976). The anterolateral muscle bundle of the left ventricle is found in about 50 per cent of normal hearts and in about 70 per cent of hearts with transposition (Oppenheimer-Dekker et al., 1976).

\section{Anatomical descriptions}

Study of the 19 hearts under discussion showed that while the morphology of the right ventricle was variable the majority of these postmortem specimens formed a distinct group. Morphological features of the right ventricle were linked to left ventricular characteristics.

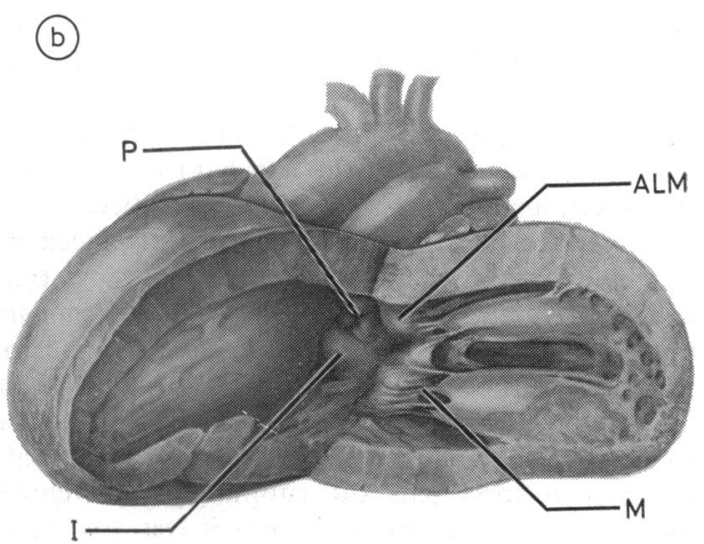

Fig. 2(a) Interior of the right ventricle of a heart with transposition of the great arteries and malalignment ventricular septal defect with less extreme leftward deviation of the infundibular septum $(I)$. A, aortic orifice; $T$, tricuspid orifice. (b) Interior of the left ventricle; same heart as Fig. 2a. Obstructing factors are the anterolateral muscle bundle of the left ventricle (ALM) and the infundibular septum $(I)$, at the left and the right of the pulmonary orifice $(P)$, respectively. $M$, mitral orifice.

I: TRANSPOSITION OF THE GREAT ARTERIES WITH MALALIGNMENT VENTRICULAR SEPTAL DEFECT

In 11 specimens there was an abnormal posterior orientation of the infundibular septum which extended into the left ventricle and resulted in an interventricular communication (Fig. 1a, 2a). In 6 cases this deviation resulted in an extreme leftward orientation of the infundibular septum; in the remaining 5 cases the leftward deviation was less in degree.

Normally the infundibular septum is incorporated on top of the ventricular septum. The consequence 
of an extreme leftward deviation of the infundibular septum is the location of the ventricular septal defect high in the right ventricular outflow tract, bounded superiorly by the under side of the posterior half of the aortic valve. A somewhat less severe deviation may also result in a high ventricular septal defect, but separated from the aortic orifice by the deviated infundibular septum.

In the 6 cases of an extreme leftward deviation of the infundibular septum and a ventricular septal defect situated high in the right ventricular outflow tract and partly bounded by aortic valve cusp, the ventricular septal defect was of a moderate to large size. In the left ventricle the outflow tract was obstructed at its right side by the deviated infundibular septum. Moreover, in 5 of the 6 specimens a prominent anterolateral muscle bundle of the left ventricle contributed to narrowing of the left ventricular outflow tract, mainly at its left side (Fig. 1a, 1b).

Both structures, infundibular septum and anterolateral muscle bundle of the left ventricle, joined at the anterior side of the pulmonary orifice. Thus, they were responsible for a posterior displacement of this orifice in the left ventricular outflow tract and consequently for its narrowing. Pulmonary mitral continuity was present in all cases. In the one specimen without an anterolateral muscle bundle of the left ventricle the obstruction was caused partly by a thickened anterior left ventricular wall. In these 6 specimens the subpulmonary stenosis was mostly severe, and in 2 cases it was associated with valvular pulmonary stenosis.

In the 5 cases with less extreme deviation of the infundibular septum and a ventricular septal defect separated from the aortic orifice by the infundibular septum, the size of the ventricular septal defect was moderate.

In the left ventricle the infundibular septum was found at the right side of the pulmonary orifice narrowing the left ventricular outflow tract. At its left anterior portion this outflow tract was obstructed by a prominent anterolateral muscle bundle of the left ventricle in 4 cases. As the infundibular septum and the anterolateral muscle bundle were not directly continuous as in the former 6 specimens, the pulmonary orifice was situated directly against the anterior left ventricular wall (Fig. 2a, 2b).

In 3 cases infundibular septum and anterolateral muscle bundle were connected by a fibromuscular spur extending between pulmonary and mitral orifices at the posterior side of the pulmonary orifice, in contradistinction to their anterior connection in the former 6 hearts. Thus, there was no pulmonary-mitral continuity. The subpulmonary stenosis was moderate to severe; in 3 cases it was associated with valvular pulmonary stenosis, once in combination with a bicuspid valve. One of these cases had a small second posteroinferior muscular ventricular septal defect.

II : TRANSPOSITION OF THE GREAT ARTERIES WITH VENTRICULAR SEPTAL DEFECT INVOLVING RIGHT VENTRICULAR INFLOW TRACT

The 8 specimens of this group had a ventricular septal defect adjacent to the septal leaflet of the tricuspid valve, a paratricuspid ventricular septal defect (Moulaert, 1978; Moulaert et al., 1977). The coexisting pulmonary stenosis varied considerably. However, 4 hearts had remarkable and similar mitral valves.

Four specimens showed a variability in structures, causing pulmonary stenosis. In 2 cases there was narrowing of the left ventricular outflow tract caused by a thickened anterior left ventricular wall; one coexisted with an adherence of the anterior portion of the anterior mitral leaflet to the ventricular septum at the anterior side of the pulmonary orifice, which aggravated the subpulmonary obstruction, and one was found in combination with a discrete fibrous subpulmonary ring. In 1 case the anterior part of the ventricular septum, which was deviated to the left, was responsible for a subpulmonary obstruction. In the fourth specimen the stenosis resulted from bulging of the mid part of the ventricular septum into the cavity of the left ventricle, associated with proliferation of mitral valvular tissue; in addition, the tricuspid valve showed proliferations, protruding through the ventricular septal defect. These 4 ventricular septal defects varied from small to large. The pulmonary stenosis was moderate.

In 4 specimens there was a cleft in the anterior mitral leaflet and the septal tricuspid leaflet had some continuity with this cleft leaflet through the ventricular septal defect. At the same time, a leftward deviation of the anterior part of the ventricular septum was found. This and the anomalous attachment of the mitral valve to the anterior part of the ventricular septum resulted in outflow tract obstruction (Fig. 3a, 3b). The size of the ventricular septal defect ranged from moderate to large. The subpulmonary obstruction in these 4 cases was moderate, one being associated with a valvular pulmonary stenosis.

\section{Discussion}

In transposition of the great arteries with ventricular septal defect many different types of pulmonary stenosis can be expected, valvular as well as sub- 

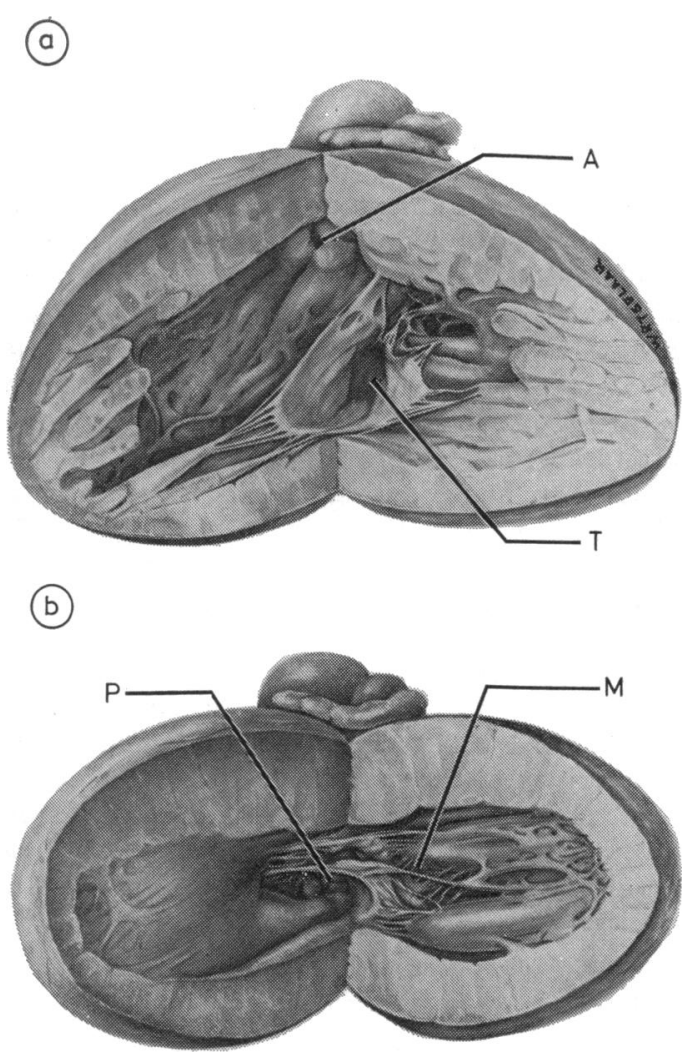

Fig. 3(a) Interior of the right ventricle of a heart with transposition of the great arteries and paratricuspid ventricular septal defect. A, aortic orifice; $T$, tricuspid orifice. (b) Interior of the left ventricle; same heart as Fig. 3a. The cleft anterior leaflet of the mitral valve is anomalously attached to the anterior part of the ventricular septum, which part is deviated leftward. M, mitral orifice; $P$, pulmonary orifice. valvular. In subvalvular pulmonary stenosis muscular structures, fibrous rings, membranous structures-either redundant mitral or tricuspid valvular tissue or proliferations of the membranous septum-and abnormal attachments or connections may be responsible for the obstruction (Elliott et al., 1963; Shaher et al., 1967a, 1967b; Daicoff et al., 1969; Rastelli et al., 1969; Fisher et al., 1970; Imamura et al., 1971; Quero-Jiménez et al., 1973; Shaher, 1973; Quero-Jiménez and Pérez Martínez, 1974; Lancelin et al., 1975; Quero-Jiménez et al., 1975; Shrivastava et al., 1976; Bühlmeyer et al., 1977; Quero-Jiménez et al., 1977; Van Praagh, 1977). As any of these different types of pulmonary stenosis can coexist with any type of transposition of the great arteries with ventricular septal defect, we shall not discuss these types: they are summarised in Table 1. We restrict ourselves to those kinds of pulmonary stenosis that, at least in our opinion, are related to either inflow or outflow development.

Our collection of 90 heart-lung specimens with transposition of the great arteries and ventricular septal defect is similar to those already described elsewhere in that nonvalvular pulmonary stenosis was found in about 21 per cent of cases; other papers have given percentages varying from 7 to 25 (Lev et al., 1961; Elliott et al., 1963; Shaher et al., 1967b; Paul et al., 1968; Imamura et al., 1971; Shaher, 1973; Quero-Jiménez et al., 1977; Van Praagh, 1977).

In this paper malalignment ventricular septal defect is described in 11 out of 19 specimens (Tables 1 and 2). This is in agreement with published figures: Elliott et al. (1963) reported 13 out of 22 patients with this type of ventricular septal defect, Imamura et al. (1971) described 5 out of 10 cases, Shaher et al. (1967b) 6 out of 11 cases, and Van Praagh (1977) 17 out of 33 cases.

The malorientation of the infundibular septum

Table 1 Relation of type and size of VSD to cause and degree of subvalvular pulmonary stenosis

\begin{tabular}{|c|c|c|c|c|c|}
\hline & \multirow{2}{*}{$\begin{array}{l}\text { No. of } \\
\text { hearts }\end{array}$} & \multicolumn{2}{|l|}{ Ventricular septal defect } & \multicolumn{2}{|l|}{ Pulmonary stenosis } \\
\hline & & Type & Size & Narrowing structures & Degree \\
\hline Malalignment VSD & 6 & Directly subaortic & Moderate to large & $\begin{array}{l}\text { Infundibular septum }+ \text { ALM: } \\
\text { joining at anterior side of } \\
\text { pulmonary orifice; } \\
\text { valvular } 2 \times\end{array}$ & Mostly severe \\
\hline Malalignment VSD & 5 & $\begin{array}{l}\text { Separated from aorta } \\
\text { by infundibular } \\
\text { septum }\end{array}$ & Moderate & $\begin{array}{l}\text { Infundibular septum + ALM: } \\
\text { right and left of pulmonary orifice; } \\
\text { valvular } 3 \times\end{array}$ & Moderate to severe \\
\hline $\begin{array}{l}\text { VSD involving right } \\
\text { ventricular inflow tract }\end{array}$ & 4 & Paratricuspid & Small to large & Variable & Moderate \\
\hline $\begin{array}{l}\text { VSD involving right } \\
\text { ventricular inflow tract }\end{array}$ & 4 & $\begin{array}{l}\text { Paratricuspid with } \\
\text { cleft mitral leaflet }\end{array}$ & Moderate to large & $\begin{array}{l}\text { Cleft anterior mitral leaflet }+ \\
\text { deviated anterior part of } \\
\text { ventricular septum }\end{array}$ & Moderate \\
\hline
\end{tabular}


Table 2 Leiden Registration Code, age at death and sex by specimen in the distinct groups

\begin{tabular}{|c|c|c|c|}
\hline Group & Catalogue No. & Age at death & Sex \\
\hline IA & $\begin{array}{r}\text { WK } 3403 \\
3633 \\
4045 \\
4402 \\
4731 \\
6100\end{array}$ & $\begin{array}{r}26 \mathrm{~d} \\
16 \mathrm{y} \\
21 \mathrm{y} \\
10 \mathrm{y} \\
4 \mathrm{y} \\
25 \mathrm{y}\end{array}$ & $\begin{array}{l}\mathrm{F} \\
\mathrm{M} \\
\mathrm{M} \\
\mathrm{M} \\
\mathrm{M} \\
\mathrm{M}\end{array}$ \\
\hline IB & $\begin{array}{r}2472 \\
3328 \\
3371 \\
3856 \\
5018\end{array}$ & $\begin{array}{l}8 \mathrm{mth} \\
3 \mathrm{y} \\
2 \frac{1}{2} \mathrm{y} \\
10 \mathrm{y} \\
25 \mathrm{~d}\end{array}$ & $\begin{array}{l}\mathrm{F} \\
\mathrm{M} \\
\mathrm{M} \\
\mathrm{F} \\
\mathrm{F}\end{array}$ \\
\hline IIA & $\begin{array}{r}\text { WK } 1245 \\
3570 \\
4963 \\
5164\end{array}$ & $\begin{array}{l}5 \mathrm{mth} \\
3 \mathrm{mth} \\
3 \mathrm{~d} \\
3 \frac{1}{2} \mathrm{y}\end{array}$ & $\begin{array}{l}\mathrm{F} \\
\mathrm{M} \\
\mathrm{M} \\
\mathrm{M}\end{array}$ \\
\hline IIB & $\begin{array}{r}\text { WK } 435 \\
884 \\
4849 \\
6134\end{array}$ & $\begin{array}{l}4 \mathrm{mth} \\
1 \mathrm{y} \\
4 \mathrm{y} \\
1 \mathrm{y}\end{array}$ & $\begin{array}{l}\mathrm{M} \\
\mathrm{M} \\
\mathrm{F} \\
\mathrm{F}\end{array}$ \\
\hline
\end{tabular}

leads to certain forms of subvalvular pulmonary stenosis. This is in keeping with some of the observations of Quero-Jiménez et al. (1973, 1975) and Quero-Jiménez and Pérez Martínez (1974). However, we want to stress that two types of pulmonary stenosis in malalignment of the infundibular septum can be distinguished: (A) An extreme leftward deviation of the infundibular septum results in pulmonary stenosis, caused by the infundibular septum together with a prominent anterolateral muscle bundle of the left ventricle, joining at the anterior side of the pulmonary orifice, which is displaced posteriorly. In the 6 cases of our collection the pulmonary stenosis was mostly severe. (B) On the other hand, our 5 cases with less extreme deviation of the infundibular septum were found to have pulmonary stenosis caused by an infundibular septum and an anterolateral muscle bundle which were separated from each other. The obstructed outflow tract was situated between these two structures, and pulmonary stenosis was less severe than in group A. Specimens with a so-called bilateral infundibulum or bilateral conus, that is neither aortic-tricuspid nor pulmonary-mitral continuity (Paul et al., 1968; Goor and Edwards, 1973; Quero-Jiménez and Pérez Martínez, 1974; Shrivastava et al., 1976), always showed a malalignment ventricular septal defect, agreeing with the findings of Shrivastava et al. (1976).

In 4 specimens with paratricuspid ventricular septal defect the mitral valve was remarkable. The pulmonary stenosis was caused by a leftward deviation of the anterior part of the ventricular septum together with an anomalous attachment of the cleft anterior mitral leaflet to the ventricular septum. This type of ventricular septal defect resembles Neufeld's 'persistent common atrioventricular canal type VSD', described in cases of isolated ventricular septal defect (Neufeld et al., 1961).

Abnormal attachment of mitral valvular tissue to the ventricular septum in cases of transposition of the great arteries with ventricular septal defect and pulmonary stenosis has been described previously in one specimen by Quero-Jiménez et al. (1973) and Bühlmeyer et al. (1977) and in 4 specimens by Rosenquist et al. (1975). A cleft in the anterior mitral leaflet has been described as well in one case by Layman and Edwards (1967), Shaher et al. (1967b), and Quero-Jiménez et al. (1973). The present study shows that these two abnormalities of the mitral valve can coexist as was described in no less than 4 cases with this combination of anomalies. It must be stressed that a contribution to the narrowing of the left ventricular outflow tract in all these 4 specimens was brought about by the condition of the mitral valve.

Similar abnormalities of the mitral valve were observed in cases of transposition of the great arteries without pulmonary stenosis. This will be described in a forthcoming publication.

\section{References}

Anderson, R. H., Becker, A. E., and Van Mierop, L. H. S. (1977). What should we call the 'crista'? British Heart Fournal, 39, 856-859.

Bühlmeyer, K., Tacke, E., and Mocellin, R. (1977). Angiocardiographic and functional studies in patients with transposition of the great arteries and left ventricular outflow tract obstruction (abstract). In Proceedings of the 15th Annual General Meeting, p. 14. Ed. by A. DevlooBlancquaert. The Association of European Paediatric Cardiologists, Gent, Belgium.

Daicoff, G. R., Schiebler, G. L., Elliott, L. P., Van Mierop, L. H. S., Bartley, T. D., Gessner, I. H., and Wheat, M. W., Jr. (1969). Surgical repair of complete transposition of the great arteries with pulmonary stenosis. Annals of Thoracic Surgery, 7, 529-538.

Elliott, L. P., Neufeld, H. N., Anderson, R. C., Adams, P., Jr., and Edwards, J. E. (1963). Complete transposition of the great vessels. I. An anatomic study of sixty cases. Circulation, 27, 1105-1117.

Fisher, E. H. R., Muster, A. J., Lev, M., and Paul, M. H. (1970). Angiocardiographic and anatomic findings in transposition of the great arteries with left ventricular outflow tract gradients (abstract). American fournal of Cardiology, 25, 95-96.

Goor, D. A., and Edwards, J. E. (1973). The spectrum of transposition of the great arteries with specific reference to developmental anatomy of the conus. Circulation, 48, 406-415.

Imamura, E. S., Morikawa, T., Tatsuno, K., Konno, S., Arai, T., and Sakakibara, S. (1971). Surgical considerations of ventricular septal defect associated with complete transposition of the great arteries and pulmonary stenosis with special reference to the Rastelli operation. Circulation, 44, 914-923. 
Lancelin, B., Pauly-Laubry, C., Guerinon, J., Tricot, J.-L., Bouchard, F., and Maurice, P. (1975). Transposition des gros vaisseaux avec sténose pulmonaire et communication interventriculaire. Aspect anatomique et chirurgical à propos de 10 observations. Archives des Maladies du Coeur et des Vaisseaux, 68, 339-351.

Layman, T. E., and Edwards, J. E. (1967). Anomalies of the cardiac valves associated with complete transposition of the great vessels. American fournal of Cardiology, 19, 247-255.

Lev, M. (1972). The conotruncus. I. Its normal inversion and conus absorption. Circulation, 46, 634-635.

Lev, M., Alcalde, V. M., and Baffes, T. G. (1961). Pathologic anatomy of complete transposition of the arterial trunks. Pediatrics, 28, 293-306.

Moulaert, A. J. (1974). Ventricular septal defects and anomalies of the aortic arch. Thesis, Leiden.

Moulaert, A. J. (1978). Anatomy of ventricular septal defect. In Paediatric Cardiology. Proceedings of the Second European Symposium of the British Heart Foundation. Churchill Livingstone, Edinburgh. In the press.

Moulaert, A. J., Bruins, C. L. D. Ch., Buis-Liem, T., and Oppenheimer-Dekker, A. (1977). Different types of ventricular septal defects with subaortic stenosis (abstract). In Proceedings of the 15th Annual General Meeting, p. 2. Ed. by A. Devloo-Blancquaert. The Association of European Paediatric Cardiologists, Gent, Belgium.

Moulaert, A. J., and Oppenheimer-Dekker, A. (1976). Anterolateral muscle bundle of the left ventricle, bulboventricular flange and subaortic stenosis. American fournal of Cardiology, 37, 78-81.

Neufeld, H. N., Titus, J. L., DuShane, J. W., Burchell, H. B., and Edwards, J. E. (1961). Isolated ventricular septal defect of the persistent common atrioventricular canal type. Circulation, 23, 685-696.

Oppenheimer-Dekker, A., Wenink, A. C. G., van Gils, F. A. W., Gittenberger-de Groot, A. C., and Moulaert, A. J. (1976). Transposition of the great arteries: morphological study of 150 cases (abstract). Fournal of Anatomy, 122, 724-725.

Paul, M. H., Van Praagh, S., and Van Praagh, R. (1968). Transposition of the great arteries. In Paediatric Cardiology, pp. 576-610. Ed. by H. Watson. Lloyd-Luke, London

Quero-Jiménez, M., Casanova Gómez, M., and Burgueros Valero, M. (1975). Tipos de comunicación interventricular en la dextrotransposición completa de las grandes arterias. Revista Española de Cardiología, 28, 469-485.
Quero-Jiménez, M., Casanova Gómez, M., Marsico, F., Quero-Jiménez, C., Calabró, R., and Burgueros Valero, $M$. (1977). Morphologic aspects of the left ventricular outflow tract in transposition of the great arteries (abstract). In Proceedings of the 15th Annual General Meeting, p. 11. Ed. by A. Devloo-Blancquaert. The Association of European Paediatric Cardiologists, Gent, Belgium.

Quero-Jiménez, M., Castro Gussoni, M. C., Moreno Granados, F., and Pérez Díaz, L. (1973). Transposition des gros vaisseaux. Anatomie pathologique. Coeur (Numéro spécial), 177-206.

Quero-Jiménez, M., and Pérez Martínez, V. (1974). Uncommon conal pathology in complete dextrotransposition of the great arteries with ventricular septal defect. Chest, 66, 411-417.

Rastelli, G. C., Wallace, R. B., and Ongley, P. A. (1969). Complete repair of transposition of the great arteries with pulmonary stenosis: a review and report of a case corrected by using a new surgical technique. Circulation, 39, 83-95.

Rosenquist, G. C., Stark, J., and Taylor, J. F. N. (1975). Congenital mitral valve disease in transposition of the great arteries. Circulation, 51, 731-737.

Shaher, R. M. (1973). Complete Transposition of the Great Arteries. Academic Press, New York and London.

Shaher, R. M., Moës, C. A. F., and Khoury, G. (1967a). Radiologic and angiocardiographic findings in complete transposition of the great vessels with left ventricular outflow tract obstruction. Radiology, 88, 1092-1099.

Shaher, R. M., Puddu, G. C., Khoury, G., Moës, C. A. F., and Mustard, W. T. (1967b). Complete transposition of the great vessels with anatomic obstruction of the outflow tract of the left ventricle. Surgical implications of anatomic findings. American fournal of Cardiology, 19, 658-670.

Shrivastava, S., Tadavarthy, S. M., Fukuda, T., and Edwards, J. E. (1976). Anatomic causes of pulmonary stenosis in complete transposition. Circulation, 54, 154-159.

Van Praagh, R. (1977). Anatomic types of left ventricular outflow tract obstruction in transposition of the great arteries (abstract). In Proceedings of the 15th Annual General Meeting, p. 10. Ed. by A. Devloo-Blancquaert. The Association of European Paediatric Cardiologists, Gent, Belgium.

Requests for reprints to Dr Frank A. W. van Gils, Department of Anatomy and Embryology, Wassenaarseweg 62, Leiden, The Netherlands. 